\title{
Direct evidence for the involvement of extracellular proteins in the adhesion of Azospirillum brasilense
}

\author{
Yves F. Dufrêne, ${ }^{1}$ Hans Vermeiren, ${ }^{2}$ Jos Vanderleyden ${ }^{2}$ \\ and Paul G. Rouxhet ${ }^{1}$ \\ Author for correspondence: Paul G. Rouxhet. Tel: +32 104735 89. Fax: +3210472005. \\ e-mail: rouxhet@cifa.ucl.ac.be
}

1 Unité de Chimie des Interfaces, Université Catholique de Louvain, Place Croix du Sud 2/18, B-1348 Louvain-la-Neuve, Belgium

2 F. A. Janssens Laboratory of Genetics, Catholic University of Leuven, Willem de Croylaan 42 B-3001 Heverlee, Belgium
Adhesion of Azospirillum brasilense to glass and polystyrene was investigated by bringing the cells into contact with the support by sedimentation. Adhesion depended on time and temperature : lower adhesion densities were observed when the contact time was only $\mathbf{2 h}$ or $6 \mathrm{~h}$, as compared to $24 \mathrm{~h}$, or when the test was performed at $4{ }^{\circ} \mathrm{C}$, as compared to $30^{\circ} \mathrm{C}$. The influence of cell physiology was further demonstrated by the effect of tetracycline, which inhibited adhesion. Scanning electron microscopy showed that cells produced extracellular material when left in contact with a support for $24 \mathrm{~h}$. The surface elemental composition of cells and of polystyrene supports after cell adhesion and subsequent detachment was determined by X-ray photoelectron spectroscopy; this provided information on the relative concentrations of proteins and polysaccharides at the surface. The protein concentration at the surface of a cell sediment increased as a function of time at $30^{\circ} \mathrm{C}$, correlating with an increase of adhesion density. A similar correlation between protein concentration and adhesion density was found when comparing exponentialphase cells with stationary-phase cells. The surface composition of polystyrene supports examined after cell detachment was found to be rich in proteins, indicating that proteins are the major constituent at the support surface. Lowering the contact time, or performing adhesion under unfavourable metabolic conditions $\left(4^{\circ} \mathrm{C}\right.$ ) or in the presence of tetracycline, resulted in a decrease in protein concentration at the support surface, which was correlated with a decrease in adhesion density. The correlation between protein concentration at the cell surface or at the support surface and adhesion density, under different experimental conditions, provides a direct demonstration of the involvement of extracellular proteins in the adhesion of A. brasilense to inert surfaces.

Keywords: Azospirillum brasilense, adhesion, extracellular proteins, $\mathrm{X}$-ray photoelectron spectroscopy

\section{INTRODUCTION}

Bacterial adhesion is a widespread phenomenon, encountered in natural environments as well as in industrial processes. Surfaces on which adhesion may occur display a great diversity (Marshall, 1991), from inanimate surfaces, such as soil particles, rocks, pipes, heat exchangers and biotechnological reactors, to animate surfaces, such as other microbial cells, plant roots and

Abbreviations: XPS, X-ray photoelectron spectroscopy. leaves, and animal tissues. Bacterial adhesion and biofilm processes have important consequences (Characklis \& Marshall, 1990; Melo et al., 1992) which can be either beneficial, such as in biotechnology (wastewater treatment, bioremediation, immobilized cells in reactors), or detrimental, such as in industrial systems (fouling, contamination) and in medicine (accumulation on teeth, implants and prosthetic devices).

The colonization of solid surfaces by micro-organisms can be described as a multi-step process (Rouxhet \& Mozes, 1990). In the first step, the cells reach the support 
surface by various transport mechanisms (diffusion, sedimentation, convection, active transport). Then initial adhesion, a process controlled by physicochemical interactions between the cells and the support, may occur. Subsequently, the production of extracellular polymers by the cells may lead to the firm attachment ('anchorage') of the cells to the support. Finally, multiplication of the attached cells may lead to the formation of microcolonies or biofilms.

The initial adhesion of bacterial cells to solid surfaces can be understood in the light of DLVO theory, which accounts for van der Waals attraction and electrostatic interactions between supposedly smooth surfaces (van Loosdrecht et al., 1989; Rouxhet \& Mozes, 1990; Rijnaarts et al., 1995); additional interactions (bridging, steric repulsion) may involve macromolecules present at the surfaces (Rijnaarts et al., 1995). An alternative approach is to consider the balance of interfacial free energies between the cell-support interface and the interface of each partner with water (Absolom et al., 1983; Busscher et al., 1984). The influence of cell or support surface hydrophobicity on adhesion has been frequently pointed out (Mozes et al., 1987; van Loosdrecht et al., 1987; Rijnaarts et al., 1995).

However, bacteria are not inert colloids but living cells capable of metabolism, growth and motility. The production of extracellular polymeric substances and of appendages (fimbriae, pili, fibrils and flagella) has been found to play a key role in the adhesion of bacteria to surfaces (Marshall, 1985). Marshall et al. (1971) suggested that the production of adhesive polymers during the early adhesion process may result in irreversible adhesion, by bridging across the repulsion barrier. Polymer accumulation between bacteria and surfaces has been directly observed by electron microscopy (Fletcher \& Floodgate, 1973; Marshall \& Cruickshank, 1973). To date, bacterial polymers have been characterized after isolation from culture supernatants or from the cell surface; however, their relevance to adhesion is not straightforward (Neu \& Marshall, 1991). For instance, Allison \& Sutherland (1987) proposed that extracellular polymers produced by freshwater bacteria may not be involved in adhesion, but rather in the biofilm matrix formation.

Little information has been obtained concerning the chemical composition of the bridging polymers, because they are available in small amounts and are located at the cell-support interface. Marshall et al. (1971) showed by electron microscopy that part of the polymers remains on the support in the form of 'footprints' after removal of the adhering cells. In a later study, footprints remaining on polystyrene after detachment of marine bacteria were examined by scanning and transmission electron microscopy and characterized using lectins combined with a fluorescent protein stain (Neu \& Marshall, 1991).

Azospirillum spp. are nitrogen-fixing bacteria that live in close association with plant roots and possess plantgrowth-promoting potential (Michiels et al., 1989; Okon, 1994). One important step in the colonization of the rhizosphere by azospirilla is their attachment to plant roots and soil particles. Attachment to sand particles (Bashan et al., 1991) and to root surfaces (Bashan et al., 1986) was found to be mediated by a network of fibrillar material. Proteins and polysaccharides have been reported to play a role in the adhesion to plant roots (Michiels $e t$ al., 1991) but the fundamental mechanisms governing the process are still not fully understood due to the lack of direct surface measurements.

In the present study, the adhesion of Azospirillum brasilense to inert surfaces was investigated with the aim of better understanding the role of compounds produced by the cells. The morphology of adhering cells was examined by scanning electron microscopy. The surface chemical composition of cells and of supports was determined by $\mathrm{X}$-ray photoelectron spectroscopy (XPS), which provides an elemental and, to a certain extent, a functional analysis of surfaces, with an analysed depth of 3-5 nm (Ratner \& McElroy, 1986; Rouxhet \& Genet, 1991 ; Rouxhet et al., 1994).

\section{METHODS}

Bacterial strain and culture conditions. Azospirillum brasilense Sp7 (ATCC 29145) was used. It was maintained by restreaking every three weeks on fresh plates of Luria-Bertani rich medium (Sambrook et al., 1989) supplemented with $2.5 \mathrm{mM} \mathrm{CaCl}_{2}$ and $2.5 \mathrm{mM} \mathrm{MgSO}_{4}\left(\mathrm{LB}^{*}\right)$. Bacteria were cultivated at $30^{\circ} \mathrm{C}$ in standard Erlenmeyer flasks on a rotary shaker (100 r.p.m.). Precultures were inoculated with material collected from several colonies on a fresh stock plate, and incubated for $10-12 \mathrm{~h}$ in $50 \mathrm{ml}$ flasks containing $10 \mathrm{ml} \mathrm{LB}$. Experimental cultures were grown in 1 litre flasks containing $200 \mathrm{ml} \mathrm{LB}^{*}$, inoculated with $2 \mathrm{ml}$ preculture. During the culture, the cell concentration increased from $6 \times 10^{6}$ to $2 \times 10^{9}$ cells ml ${ }^{-1}$. Cells were collected $12 \mathrm{~h}$ or $24 \mathrm{~h}$ after inoculation, corresponding to the exponential phase and the stationary phase, respectively. They were harvested by centrifugation at $13400 \mathrm{~g}$ for $10 \mathrm{~min}$, washed three times by resuspension in demineralized water and centrifugation and finally resuspended in water to a concentration of $6 \times 10^{8}$ cells $\mathrm{ml}^{-1}$. The cell concentration of the suspension was determined by direct count and by measuring $\mathrm{OD}_{600}$. A comparison of demineralized water and culture medium as the resuspending fluid showed that no loss of viability occurred after brief exposure $(2 \mathrm{~h})$ of cells to demineralized water.

Supports. Glass and polystyrene were selected as model supports, representing hydrophilic and hydrophobic surfaces, respectively. Glass samples were microscope slides (Menzel Glazer, Germany); they were cleaned by immersion overnight in sulfochromic mixture, and rinsed with demineralized water prior to the adhesion tests. Polystyrene Petri dishes (Merck) were used as hydrophobic supports; their hydrophobicity was always checked before use (water contact angle around $90^{\circ}$ ).

Adhesion test. Adhesion experiments were performed in static conditions using a procedure similar to that described previously (Mozes et al., 1987), which brings the cells into contact with the supports (glass and polystyrene) by sedimentation. Cell suspension $(30 \mathrm{ml})$ was poured into a Petri dish containing a glass plate. In certain experiments, tetracycline was added at an inhibitory concentration $\left(200 \mathrm{mg} \mathrm{l}^{-1}\right)$ or a sub-minimal inhibitory concentration $\left(1 \mathrm{mg} \mathrm{l}^{-1}\right)$. The suspension was left undisturbed for a given time $(2,6$ or $24 \mathrm{~h})$, at $30^{\circ} \mathrm{C}$ or $4{ }^{\circ} \mathrm{C}$. The glass plate was then withdrawn and rinsed either mildly, by vertical immersion with gentle agitation $(15 \mathrm{~s})$ in three baths of 
demineralized water, or drastically, by sprinkling it with a water jet. The Petri dish was rinsed either mildly by filling three times with demineralized water and gentle stirring, or drastically. The wet support was immediately observed under the microscope, before drying. The entire support surface was examined, to ensure that the adhesion pattern was homogeneous, and three representative photographs were taken. If the pattern was nonhomogeneous, which occurred rarely, the sample was not considered for analysis. The number of adhering cells was determined by counting the three photographs for each adhesion experiment.

Scanning electron microscopy. Cells adhering on glass and on polystyrene supports were examined by scanning electron microscopy. A $30 \mathrm{ml}$ portion of a suspension of exponentialphase cells was poured into a Petri dish containing small supports (squares of about $1 \mathrm{~cm}$ ). After $2 \mathrm{~h}$ or $24 \mathrm{~h}$ contact time at $30{ }^{\circ} \mathrm{C}$ the supports were mildly rinsed as described above. The samples were immediately fixed by immersion for $2 \mathrm{~h}$ in a solution of $3 \%(\mathrm{v} / \mathrm{v})$ glutaraldehyde and $0.1 \mathrm{M}$ sodium cacodylate, and kept overnight in $0.1 \mathrm{M}$ sodium cacodylate. They were then dehydrated by successive $15 \mathrm{~min}$ immersions in water/ethanol mixtures at 25, 50, 70, 80, 90, 95 and $100 \%$ (v/v) ethanol, and dried in a $\mathrm{CO}_{2}$ atmosphere in a critical-point dryer (Polaron E3000). Samples were coated with gold by a diode sputtering system (Polaron E5100) and examined using a scanning electron microscope (Philips XL20) at $20 \mathrm{kV}$.

Sample preparation for XPS analysis. Polystyrene was analysed by XPS after cell adhesion and subsequent detachment by ultrasonication in demineralized water (several consecutive steps of $15 \mathrm{~s}$ until optical microscope observation showed that all cells were detached). Examination of several sonicated supports by scanning electron microscopy confirmed cell detachment and did not reveal the presence of cell fragments. The sonicated dishes were held vertically to allow drainage of the liquid film when present, then dried overnight at $30^{\circ} \mathrm{C}$ in a room atmosphere, and finally stored at room temperature in a desiccator containing $\mathrm{P}_{2} \mathrm{O}_{5}$. Before XPS analysis, squares of about $1 \mathrm{~cm}$ were cut from the bottom with a hot blade.

Cell sediments were analysed after the following preparation procedure. Cells harvested in the exponential phase were allowed to settle down onto polystyrene plates (squares of about $1 \mathrm{~cm}$ ), at $4{ }^{\circ} \mathrm{C}$ and at $30^{\circ} \mathrm{C}$, and left undisturbed for $24 \mathrm{~h}$. Supports were also examined after sedimentation of cells at $30^{\circ} \mathrm{C}$ and mild rinsing. Unrinsed and rinsed supports were immediately immersed in liquid nitrogen and freeze-dried, using a freeze-dryer specially designed by Leybold (P. B. Dengis \& P. G. Rouxhet, unpublished). The freeze-dryer shelf was precooled at $-50{ }^{\circ} \mathrm{C}$. The temperature was maintained at $-50{ }^{\circ} \mathrm{C}$ for $3 \mathrm{~h}$, then raised progressively to $-5^{\circ} \mathrm{C}$ in about $15 \mathrm{~h}$, maintained at $-5{ }^{\circ} \mathrm{C}$ for $6-12 \mathrm{~h}$, and finally raised to $25^{\circ} \mathrm{C}$. Freeze-dried samples were stored at room temperature in a desiccator containing $\mathrm{P}_{2} \mathrm{O}_{5}$.

Surface analysis by XPS. The XPS analyses were performed with an SSI X-Probe (SSX-100/206) photoelectron spectrometer from Fisons, interfaced with a Hewlett Packard 9000/310 computer allowing instrument control, data accumulation and data treatment. The pressure during analysis was between $2.5 \times 10^{-6}$ and $2.5 \times 10^{-7} \mathrm{~Pa}$. The spectrometer used monochromatized $\mathrm{Al} \mathrm{K}_{\alpha} \mathrm{X}$-ray radiation $(1486.6 \mathrm{eV})$. The irradiated zone was an elliptical spot, with a shorter axis of $1000 \mu \mathrm{m}$. The constant pass energy in the hemispherical analyser was $150 \mathrm{eV}$ and $50 \mathrm{eV}$ for survey analysis and individual peak analysis, respectively. The flood gun energy was set at $10 \mathrm{eV}$ and a nickel grid was placed $3 \mathrm{~mm}$ above the surface. The following sequences of spectra were recorded: $C_{1 s}, O_{1 s}, N_{1 s}$, survey spectrum and finally $\mathrm{C}_{1 \mathrm{~s}}$ again to check for the absence of sample degradation. To assess the level of surface contamination, $C_{1 s}$ and $\mathrm{O}_{1 \mathrm{~s}}$ peaks and a survey spectrum were recorded on sorbitol, freeze-dried with the samples, and on bare polystyrene.

The binding energies were determined by reference to the $C_{1 s}$ component due to carbon bound only to carbon or hydrogen, set at $284.8 \mathrm{eV}$. The background was subtracted linearly. The data treatment was performed with the ESCA 8.3 D software provided by the spectrometer manufacturer. The atom concentrations relative to carbon (mole/mole) were calculated from the peak areas normalized on the basis of acquisition parameters and of sensitivity factors proposed by the manufacturer [mean free path varying according to the 0.7 th power of the photoelectron kinetic energy; Scofield cross-sections (Scofield, 1976); transmission function assumed to be constant]. The $C_{1 s}$ and $\mathrm{O}_{1 \mathrm{~s}}$ peaks were decomposed by using the software leastsquares fitting routine with a Gaussian/Lorentzian ratio of $85 / 15$, following a methodology described below.

\section{RESULTS}

\section{Adhesion}

Table 1 shows the influence of several factors on the density of $A$. brasilense adhering on glass and polystyrene: culture age, rinsing, contact time, temperature, and presence of tetracycline. The standard deviations calculated on the three photographs indicated that the variability of adhesion densities was satisfactory. A duplicate experiment (data not presented) gave similar results. Adhesion of cells harvested in the exponential phase, after $24 \mathrm{~h}$ contact time at $30{ }^{\circ} \mathrm{C}$ and mild rinsing (standard conditions), was clearly denser on polystyrene than on glass. Under the same conditions, cells harvested in the stationary phase adhered in higher numbers, with a similar density on both supports.

With cells harvested in the exponential phase, the density of adhering cells was lower on supports drastically rinsed (water jet), as compared with supports mildly rinsed; it

Table 1. Density of $A$. brasilense cells adhering on glass and polystyrene as a function of various parameters

\begin{tabular}{|lcc|}
\hline & \multicolumn{2}{c|}{ Cell density $\left(\mathbf{( 1 0}^{4} \text { cells } \mathbf{~ c m}^{-2}\right)^{*}$} \\
\cline { 2 - 3 } & Glass & Polystyrene \\
\hline Standard conditionst & $220(40)$ & $587(61)$ \\
Variants: & & \\
$\quad$ Stationary-phase cells & $1157(82)$ & $982(81)$ \\
Drastic rinsing & $88(14)$ & $163(18)$ \\
Contact time 6 $\mathrm{h}$ & $9(<1)$ & $<1$ \\
Contact time $\mathrm{h}$ & $<1$ & $<1$ \\
Temperature 4 ${ }^{\circ} \mathrm{C}$ & $14(1)$ & $<1$ \\
Tetracycline $\left(200 \mathrm{mg} \mathrm{l}^{-1}\right)$ & $63(12)$ & $132(17)$ \\
\hline
\end{tabular}

* The results are means of data from three photographs, with the standard deviation in parentheses.

† Standard conditions: exponential-phase cells; mild rinsing; $24 \mathrm{~h}$ contact time; temperature $30^{\circ} \mathrm{C}$. 

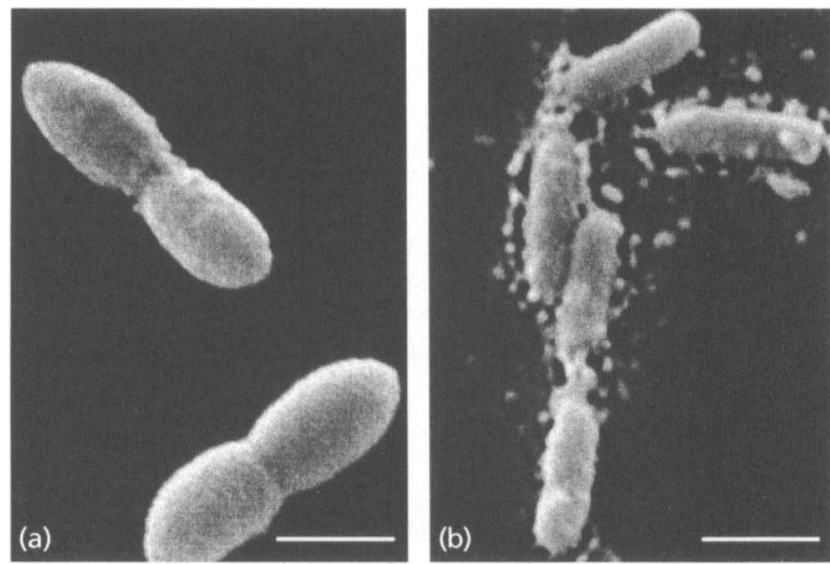

Fig. 1. Scanning electron micrographs of $A$. brasilense cells adhering on glass after $2 \mathrm{~h}$ (a) and $24 \mathrm{~h}$ (b) contact time at $30^{\circ} \mathrm{C}$; cells harvested in the exponential phase; mild rinsing. Bars, $1 \mu \mathrm{m}$.

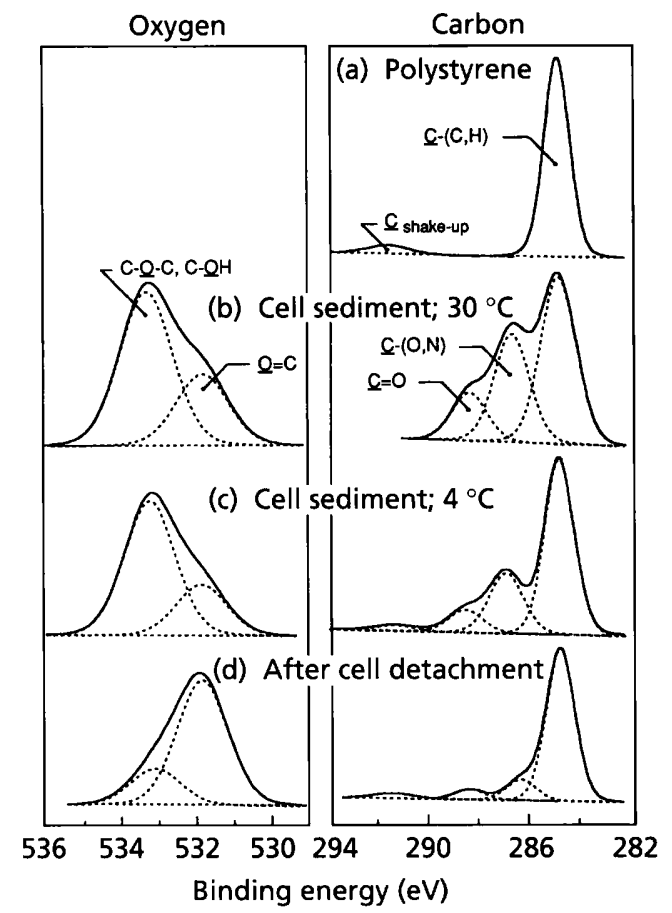

Fig. 2. Representative $C_{15}$ (right) and $O_{15}$ (left) peaks of bare polystyrene (a), of cell sediments (exponential-phase cells, $24 \mathrm{~h}$ contact time) prepared at $30^{\circ} \mathrm{C}$ (b) and at $4{ }^{\circ} \mathrm{C}$ (c), and of polystyrene after $24 \mathrm{~h}$ contact time with exponential-phase cells at $30^{\circ} \mathrm{C}$ and subsequent detachment of the adhering cells (d).

was very low when the contact time was $6 \mathrm{~h}$ or $2 \mathrm{~h}$ instead of $24 \mathrm{~h}$, or when the test was performed at $4{ }^{\circ} \mathrm{C}$.

Addition of tetracycline at $200 \mathrm{mg} \mathrm{l}^{-1}$ (inhibitory concentration) caused a substantial decrease in adhesion density. Similar results (not presented) were obtained with a sub-minimal inhibitory concentration of tetracycline $\left(1 \mathrm{mg} \mathrm{l}^{-1}\right)$.

\section{Scanning electron microscopy of adhering cells}

Fig. 1 shows scanning electron micrographs of $A$. brasilense cells harvested in the exponential phase, adhering on glass after $2 \mathrm{~h}$ and $24 \mathrm{~h}$ contact time at $30^{\circ} \mathrm{C}$ followed by mild rinsing. Cells adhering after $2 \mathrm{~h}$ contact time appeared as single and well-defined vibrioids (Fig. 1a), whereas 24 -h-old cells were characterized by a smaller size and a rod-like shape, and appeared to be surrounded by small particles which may be attributed to collapsed extracellular material (Fig. 1b). Examination of cells adhering on polystyrene failed to give satisfactory results due to the quick fracture of the gold coating upon irradiation.

\section{Surface chemical composition}

Fig. 2(a-c) shows $\mathrm{C}_{1 \mathrm{~s}}$ and $\mathrm{O}_{1 \mathrm{~s}}$ XPS peaks of bare polystyrene and of cell sediments (exponential-phase cells, $24 \mathrm{~h}$ contact time) obtained at $30^{\circ} \mathrm{C}$ and $4{ }^{\circ} \mathrm{C}$. The carbon peaks were decomposed into four components: (i) a component set at $284 \cdot 8 \mathrm{eV}$, due to carbon bound only to carbon and hydrogen $\mathrm{C}-(\mathrm{C}, \mathrm{H})$; (ii) a component at $286.8 \mathrm{eV}$ due to carbon singly bound to oxygen or nitrogen $\mathrm{C}-(\mathrm{O}, \mathrm{N})$, including ether, alcohol, amine and amide; (iii) a component at $288.4 \mathrm{eV}$ due to carbon making one double bond or two single bonds with oxygen, including amide, carbonyl, carboxylate, ester, acetal and hemiacetal - for the sake of simplicity this is represented below by $\mathrm{C}=\mathrm{O}$; (iv) a shake-up component at $291.4 \mathrm{eV}$, due to an energy loss attributed to a $\pi \rightarrow \pi^{*}$ transition, characteristic of the aryl moiety in polystyrene. The broad oxygen peak was tentatively decomposed into two components: (i) a component at $531.9 \mathrm{eV}$ attributed to oxygen making a double bond with carbon $(\underline{\mathrm{O}}=\mathrm{C})$, in carboxylic acid, carboxylate, ester, carbonyl or amide; (ii) a component at $533.3 \mathrm{eV}$, attributed to hydroxide $(\mathrm{C}-\underline{\mathrm{OH}})$, acetal and hemiacetal $(\mathrm{C}-\underline{\mathrm{O}}-\mathrm{C}-\underline{\mathrm{O}}-\mathrm{C})$. The $\mathrm{C}_{1 \mathrm{~s}}$ and $\mathrm{O}_{1 \mathrm{~s}}$ peaks were decomposed in two steps. In a first fitting, the initial binding energy, full width at halfmaximum and intensity of the components were obtained without imposing constraints. A second fitting of the $C_{1 s}$ peak was performed by imposing the same full width at half-maximum for the three components of the cell sediments at $30^{\circ} \mathrm{C}$, or for the second and the third components of other samples, and selecting the mean value obtained for these components in the first fitting; for the $O_{1 s}$ peak, the full width at half-maximum of the two components was set equal to the mean value obtained with the first fitting. Nitrogen appeared at $400 \cdot 4 \mathrm{eV}$, attributable to unprotonated amine or amide functions (Rouxhet \& Genet, 1991; Gerin et al., 1995).

Table 2 (top) presents the surface elemental compositions, expressed as atomic concentration ratios with respect to total carbon, determined by XPS on pure polystyrene, on cell sediments obtained at $30^{\circ} \mathrm{C}$ and $4{ }^{\circ} \mathrm{C}$ (exponentialphase cells, $24 \mathrm{~h}$ contact time), and on polystyrene after sedimentation of cells (exponential-phase cells, $24 \mathrm{~h}$ contact time) and mild rinsing. Good agreement was obtained between two sets of independent experiments using different cultures. 
Table 2. Surface composition determined by XPS on polystyrene, $A$. brasilense cell sediments, and polystyrene after cell adhesion under different conditions and subsequent detachment

The data, expressed as atomic concentration ratios with respect to total carbon, are from two independent sets of determinations with different bacterial cultures. Exp, cells harvested in the exponential phase; Stat, cells harvested in the stationary phase.

\begin{tabular}{|c|c|c|c|c|c|c|c|}
\hline & \multicolumn{4}{|c|}{$\mathrm{C}_{\mathrm{ts}}$} & \multicolumn{2}{|c|}{$\mathbf{O}_{1 \mathrm{~s}}$} & \multirow{2}{*}{$\frac{\mathbf{N}_{1 \mathrm{~s}}}{\mathrm{~N} / \mathrm{C}}$} \\
\hline & $\underline{\mathbf{C}}-(\mathrm{C}, \mathrm{H}) / \mathrm{C}$ & $\underline{\mathrm{C}}-(\mathrm{O}, \mathrm{N}) / \mathrm{C}$ & $\underline{C}=0 / C$ & $\underline{\mathrm{C}}_{\mathrm{sh}} * / \mathrm{C}$ & $\underline{\mathrm{O}}=\mathrm{C} / \mathrm{C}$ & $\begin{array}{l}(\mathrm{C}-\underline{\mathrm{O}}-\mathrm{C} \\
\mathrm{C}-\underline{\mathrm{O}} \mathrm{H}) / \mathrm{C}\end{array}$ & \\
\hline \multicolumn{8}{|c|}{ Bare polystyrene } \\
\hline & 0.93 & $0 \cdot 00$ & $0 \cdot 00$ & $0 \cdot 07$ & 0.00 & $0 \cdot 00$ & $0 \cdot 00$ \\
\hline & $0 \cdot 94$ & $0 \cdot 00$ & $0 \cdot 00$ & 0.06 & 0.00 & $0 \cdot 00$ & 0.00 \\
\hline \multicolumn{8}{|c|}{ Cell sediment (Exp; 24 h contact time) } \\
\hline \multirow[t]{2}{*}{$30{ }^{\circ} \mathrm{C}$} & $0 \cdot 45$ & $0 \cdot 35$ & $0 \cdot 19$ & $0 \cdot 01$ & $0 \cdot 09$ & $0 \cdot 23$ & $0 \cdot 11$ \\
\hline & $0 \cdot 50$ & $0 \cdot 33$ & $0 \cdot 15$ & 0.02 & $0 \cdot 12$ & 0.25 & $0 \cdot 10$ \\
\hline \multirow[t]{2}{*}{$4{ }^{\circ} \mathrm{C}$} & $0 \cdot 58$ & $0 \cdot 29$ & $0 \cdot 10$ & $0 \cdot 03$ & $0 \cdot 08$ & $0 \cdot 23$ & $0 \cdot 05$ \\
\hline & $0 \cdot 62$ & $0 \cdot 25$ & 0.09 & $0 \cdot 03$ & 0.07 & $0 \cdot 21$ & $0 \cdot 05$ \\
\hline \multicolumn{8}{|c|}{ Polystyrene after cell sedimentation and mild rinsing (Exp; 24 h contact time at $30^{\circ} \mathrm{C}$ ) } \\
\hline & $0 \cdot 67$ & $0 \cdot 20$ & 0.08 & $0 \cdot 04$ & 0.08 & $0 \cdot 13$ & 0.06 \\
\hline & $0 \cdot 71$ & $0 \cdot 17$ & 0.08 & $0 \cdot 04$ & $0 \cdot 07$ & $0 \cdot 11$ & $0 \cdot 06$ \\
\hline \multicolumn{8}{|c|}{ Polystyrene after detachment of adhering cells } \\
\hline \multicolumn{8}{|c|}{ Culture age $\left(24 \mathrm{~h}\right.$ contact time at $\left.30^{\circ} \mathrm{C}\right)$} \\
\hline \multirow[t]{2}{*}{ Exp } & 0.77 & $0 \cdot 13$ & 0.06 & $0 \cdot 04$ & 0.07 & 0.03 & 0.07 \\
\hline & 0.76 & $0 \cdot 14$ & 0.07 & $0 \cdot 03$ & 0.07 & 0.03 & $0 \cdot 08$ \\
\hline \multirow[t]{2}{*}{ Stat } & $0 \cdot 74$ & $0 \cdot 14$ & 0.08 & $0 \cdot 04$ & $0 \cdot 09$ & 0.03 & $0 \cdot 08$ \\
\hline & 0.77 & $0 \cdot 13$ & $0 \cdot 07$ & $0 \cdot 03$ & $0 \cdot 08$ & 0.04 & $0 \cdot 08$ \\
\hline \multicolumn{8}{|c|}{ Contact time $\left(\mathrm{Exp}, 30^{\circ} \mathrm{C}\right)$} \\
\hline \multirow[t]{2}{*}{$2 \mathrm{~h}$} & $0 \cdot 90$ & $0 \cdot 04$ & $0 \cdot 00$ & 0.06 & $0 \cdot 00$ & 0.04 & 0.01 \\
\hline & $0 \cdot 92$ & $0 \cdot 06$ & $0 \cdot 01$ & $0 \cdot 01$ & $0 \cdot 02$ & $0 \cdot 01$ & $0 \cdot 01$ \\
\hline \multirow[t]{2}{*}{$6 \mathrm{~h}$} & 0.82 & $0 \cdot 10$ & 0.04 & 0.04 & $0 \cdot 05$ & $0 \cdot 02$ & $0 \cdot 05$ \\
\hline & 0.83 & $0 \cdot 09$ & 0.03 & 0.05 & 0.05 & 0.03 & $0 \cdot 05$ \\
\hline \multicolumn{8}{|c|}{ Temperature (Exp, $24 \mathrm{~h}$ contact time) } \\
\hline \multirow[t]{2}{*}{$4^{\circ} \mathrm{C}$} & $0 \cdot 85$ & 0.09 & 0.02 & 0.04 & 0.03 & $0 \cdot 02$ & 0.03 \\
\hline & $0 \cdot 89$ & $0 \cdot 06$ & $0 \cdot 01$ & 0.04 & 0.03 & $0 \cdot 02$ & 0.03 \\
\hline \multicolumn{8}{|c|}{ Presence of tetracycline $\left(\right.$ Exp, $24 \mathrm{~h}$ contact time at $30^{\circ} \mathrm{C}$ ) } \\
\hline & $0 \cdot 80$ & $0 \cdot 12$ & $0 \cdot 04$ & $0 \cdot 04$ & 0.03 & $0 \cdot 06$ & 0.03 \\
\hline & $0 \cdot 82$ & $0 \cdot 11$ & $0 \cdot 03$ & $0 \cdot 04$ & $0 \cdot 04$ & 0.05 & 0.03 \\
\hline
\end{tabular}

${ }^{*} \mathrm{C}_{\mathrm{sh}}$, shake-up component of the carbon peak.

The results obtained on cell sediments prepared at $4{ }^{\circ} \mathrm{C}$ show a contribution of the polystyrene support revealed by the shake-up peak in Fig. 2(c), indicating the presence of cracks in the freeze-dried cell sediment. As compared with those obtained at $30^{\circ} \mathrm{C}$ (Table 2) they are characterized by lower N/O, $\underline{C}=\mathrm{O} / \underline{\mathrm{C}}-(\mathrm{O}, \mathrm{N})$ and $\underline{\mathrm{O}}=\mathrm{C} /(\mathrm{C}-\underline{\mathrm{O}} \mathrm{H}, \mathrm{C}-\underline{\mathrm{O}}-\mathrm{C})$ surface concentration ratios. It is interesting to note that a similar difference was observed between exponential-phase cells and stationaryphase cells (Y. F. Dufrêne \& P. G. Rouxhet, unpublished).

Fig. 2(d) shows XPS spectra of polystyrene examined after adhesion of $A$. brasilense (standard conditions: exponential-phase cells, $24 \mathrm{~h}$ contact time at $30^{\circ} \mathrm{C}$ ), rinsing and subsequent detachment. The $\mathrm{C}_{1 \mathrm{~s}}$ and $\mathrm{O}_{1 \mathrm{~s}}$ peaks were decomposed as described above. The binding energy of some components was slightly shifted, compared to those of cell sediments: the $\underline{C}-(\mathrm{O}, \mathrm{N})$ and $\underline{C}=\mathrm{O}$ components of the carbon peak were found respectively at 286.2 and $288.3 \mathrm{eV}$, the $\underline{\mathrm{O}}=\mathrm{C}$ and $(\mathrm{C}-\underline{\mathrm{O}} \mathrm{H}, \mathrm{C}-\underline{\mathrm{O}}-\mathrm{C})$ components of the oxygen peak were found at 531.7 and $532.8 \mathrm{eV}$ respectively, and nitrogen appeared at $400 \cdot 3 \mathrm{eV}$.

Table 2 (bottom) shows the surface elemental compositions determined on polystyrene after detachment of cells that had previously adhered under various conditions. After adhesion and detachment of stationaryphase cells kept in contact with the support for $24 \mathrm{~h}$ at $30{ }^{\circ} \mathrm{C}$, the surface composition of the supports was rich in oxygen, nitrogen and oxidized carbon, reflecting the presence of biochemical compounds. As a corollary to the 
appearance of the $\underline{\mathrm{C}}-(\mathrm{O}, \mathrm{N})$ and $\underline{\mathrm{C}}=\mathrm{O}$ components, the relative intensity of the $\mathrm{C}_{1 \mathrm{~s}}$ shake-up component, characteristic of polystyrene, decreased due to screening by adsorbed compounds. For cells harvested in the exponential phase, the surface composition observed after cell-support contact of $24 \mathrm{~h}$ and subsequent cell detachment was similar to that observed with stationaryphase cells. Lower $\underline{C}=\mathrm{O} / \mathrm{C}, \underline{\mathrm{O}}=\mathrm{C} / \mathrm{C}$ and $\mathrm{N} / \mathrm{C}$ surface concentration ratios were observed when the contact time was only $2 \mathrm{~h}$ or $6 \mathrm{~h}$, and when adhesion was performed at $4{ }^{\circ} \mathrm{C}$ or in the presence of tetracycline $\left(200 \mathrm{mg} \mathrm{l}^{-1}\right)$.

\section{DISCUSSION}

\section{Factors influencing adhesion of microbial cells}

The results in Table 1 show that the trends concerning the influence of experimental conditions on cell adhesion are the same for glass and polystyrene. The density of adhering cells is strongly reduced by drastic rinsing, indicating reversibility of adhesion with respect to shear. It has been reported that adhesion of $A$. brasilense $\mathrm{Cd}$ cells to quartz sand (Bashan \& Levanony, 1988) or wheat root surfaces (Bashan et al., 1986) is relatively weak. Reversibility with respect to shear has also been found for other bacteria (van Loosdrecht et al., 1989).

Adhesion of $A$. brasilense depends on contact time and on temperature: the adhesion density is lower when the contact time is only $2 \mathrm{~h}$ or $6 \mathrm{~h}$ compared to $24 \mathrm{~h}$, or when adhesion is performed at $4{ }^{\circ} \mathrm{C}$ compared to $30^{\circ} \mathrm{C}$. Two interpretations may account for this effect. On the one hand, it may be attributed to a slow kinetics: it is expected that, as the cells are approaching the support, they encounter an important potential energy barrier (hundreds of $\mathrm{kT}$ ) due to electrostatic repulsions between the two surfaces (Rijnaarts et al., 1995). Therefore, an increase in time and temperature should increase the number of cells which cross the potential barrier. On the other hand, the influence of time and temperature may reflect the influence of cell physiology, and in particular of the synthesis of adhesive macromolecules. The electron micrographs in Fig. 1 indicate that $A$. brasilense cells produce extracellular material when left in contact with a support for $24 \mathrm{~h}$. Marshall et al. (1971) showed that adhesion of marine bacteria is a two-stage process, an instantaneous reversible step being followed by a timedependent irreversible step. Polymeric fibrils observed by electron microscopy were suggested to be involved in the irreversible adhesion step. Also for Rbizobium bacteria (Smit et al., 1992) and for A. brasilense (Michiels $t$ t al., 1991) a two-step mechanism was proposed for the attachment to plant roots.

The influence of cell metabolism on adhesion is demonstrated by the action of tetracycline, an antibiotic known to inhibit protein synthesis. The fact that adhesion is reduced even in the presence of sub-minimal inhibitory concentrations indicates that protein synthesis is required. Tetracycline may inhibit either the synthesis of attachment proteins or the production of enzymes necessary for the synthesis of macromolecules, like polysaccharides, involved in adhesion. Fletcher (1980) demonstrated, by using a range of metabolic inhibitors, that both energy production and protein synthesis may be required for attachment of marine bacteria to solid surfaces. Growth of Actinomyces viscosus and Bacteroides gingivalis in the presence of sublethal concentrations of tetracycline was found to reduce fimbriation, cell hydrophobicity (Peros et al., 1985) and attachment to experimental salivary pellicles (Peros \& Gibbons, 1982). The influence of chloramphenicol on the aggregation of $A$. brasilense $\mathrm{Cd}$ was taken as evidence for the involvement of proteins (Madi \& Henis, 1989).

Observations supporting the notion that active bacterial metabolism is required for attachment of $A$. brasilense to roots and inert surfaces are accumulating. Killing bacteria by $\gamma$-irradiation or by heat inhibited attachment to plant roots (Bashan et al., 1986; Gafny et al., 1986; Eyers et al., 1988 ) and to sand particles (Bashan \& Levanony, 1988). However, these treatments may also alter the cell surface properties. The anchoring of $A$. brasilense to polystyrene and wheat roots was found to be reduced by several bacterial-inhibitory substances (Bashan \& Holguin, 1993).

\section{Surface composition of the cells and of the supports}

The binding energy of the $\mathrm{N}_{1 \mathrm{~s}}$ peak $(400 \cdot 4 \mathrm{eV})$ is characteristic of unprotonated amine or amide. No protonated amine was detected at $401 \cdot 3 \mathrm{eV}$. Fig. 3 is a plot of the atomic concentration ratios, with respect to total carbon, of oxygen making a double bond with carbon $\mathrm{O}=\mathrm{C} / \mathrm{C}$ (open symbols) and of carbon making a double bond or two single bonds with oxygen $\mathrm{C}=\mathrm{O} / \mathrm{C}$ (filled symbols), as a function of the $\mathrm{N} / \mathrm{C}$ ratio. With polystyrene after detachment of adhering cells or after cell sedimentation and rinsing, the regression has a slope close to unity with a small intercept. This shows that the concentrations of $\underline{\mathrm{O}}=\mathrm{C}, \underline{\mathrm{C}}=\mathrm{O}$ and $\mathrm{N}$ are close to a $1: 1: 1$ ratio, which is the ratio expected for the amide function $(\mathrm{O}=\mathrm{C}-\mathrm{N})$, in other words that nitrogen is mainly present in amide functions, which is compatible with the presence of proteins. For cell sediments, $\underline{C}=\mathrm{O} / \mathrm{C}$ is systematically higher than $\underline{\mathrm{O}}=\mathrm{C} / \mathrm{C}$ and $\mathrm{N} / \mathrm{C}$. This was also observed for the surface of cells (Y. F. Dufrêne \& P. G. Rouxhet, unpublished) and was attributed to acetal functions present in polysaccharides, the latter being revealed by the high $(\mathrm{C}-\underline{\mathrm{O}}-\mathrm{C}, \mathrm{C}-\underline{\mathrm{O}} \mathrm{H}) / \mathrm{C}$ ratios.

The XPS data are consistent with the presence of polystyrene, proteins and polysaccharides. For ease of comparison the discussion will be based on molecular composition rather than on direct elemental or functional data. The molecular composition of the analysed surfaces has been considered to comprise four model constituents: proteins (Pr), polysaccharides (PS), hydrocarbon-like compounds typical of biological material (HCbio) and of the polystyrene support (sup). The chemical composition of the model constituents is given in Table 3; it corresponds to $\mathrm{C}_{6} \mathrm{H}_{10} \mathrm{O}_{5}$ for polysaccharides, $\mathrm{CH}_{2}$ for biological hydrocarbon-like compounds and $\mathrm{C}_{8} \mathrm{H}_{8}$ for polystyrene. The amino acid composition considered for 


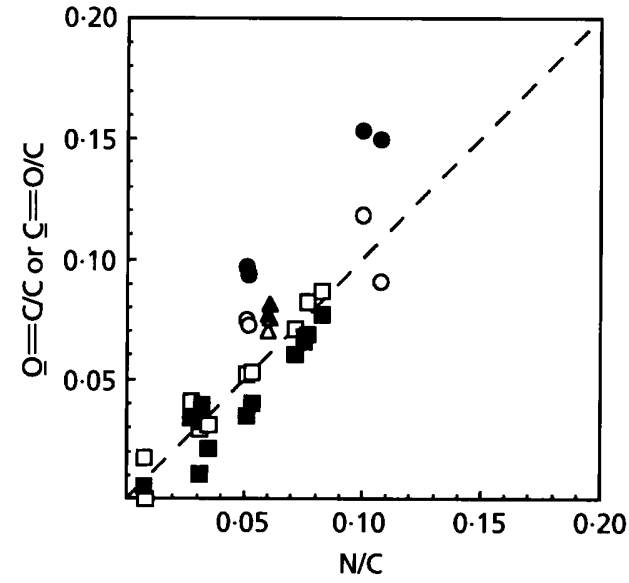

Fig. 3. Atomic concentration ratios, with respect to total carbon, of oxygen making a double bond with carbon $(\mathrm{O}=\mathrm{C}$, open symbols) and of carbon making a double bond or two single bonds with oxygen ( $\mathrm{C}=\mathrm{O}$, filled symbols) as a function of the $N / C$ concentration ratio (data from Table 2); $O, 0$, Cell sediments at $30^{\circ} \mathrm{C}$ and at $4{ }^{\circ} \mathrm{C} ; \Delta, \Delta$, polystyrene after cell sedimentation at $30^{\circ} \mathrm{C}$ and mild rinsing; $\square, \square$, polystyrene after cell adhesion under different conditions and detachment. Dashed line, relation expected for amide function.

the surface proteins and used to calculate the elemental composition is that of the major outer-membrane protein of Pseudomonas fuorescens OE 28.3 (De Mot et al., 1992). In order to assess the proportion of carbon associated with polystyrene $\left(\mathrm{C}_{\text {sup }} / \mathrm{C}\right)$, the relative intensity of the shakeup component observed on the sample, $\left(\mathrm{C}_{\mathrm{sh}} / \mathrm{C}\right)_{\text {obs }}$, was divided by the ratio $\left(\mathrm{C}_{\mathrm{sh}} / \mathrm{C}\right)_{\text {bare }}$ obtained on pure polystyrene.

Considering the average composition of the constituents, the proportion of carbon associated with each molecular constituent, $\left(\mathrm{C}_{\mathrm{Pr}} / \mathrm{C}\right),\left(\mathrm{C}_{\mathrm{PS}} / \mathrm{C}\right),\left(\mathrm{C}_{\mathrm{HCbio}} / \mathrm{C}\right)$ and $\left(\mathrm{C}_{\mathrm{sup}} / \mathrm{C}\right)$ was obtained by solving the following system of equations:

$(\mathrm{N} / \mathrm{C})_{\text {obs }}=0.279\left(\mathrm{C}_{\mathrm{Pr}} / \mathrm{C}\right)$

$(\mathrm{O} / \mathrm{C})_{\text {obs }}=0.325\left(\mathrm{C}_{\mathrm{Pr}} / \mathrm{C}\right)+0.833\left(\mathrm{C}_{\mathrm{PS}} / \mathrm{C}\right)$

$(\mathrm{C} / \mathrm{C})_{\mathrm{obs}}=\left(\mathrm{C}_{\mathrm{Pr}} / \mathrm{C}\right)+\left(\mathrm{C}_{\mathrm{PS}} / \mathrm{C}\right)+\left(\mathrm{C}_{\mathrm{HCbio}} / \mathrm{C}\right)$

$\left(\mathrm{C}_{\mathrm{sh}} / \mathrm{C}\right)_{\text {obs }}=\left(\mathrm{C}_{\mathrm{sup}} / \mathrm{C}\right)\left(\mathrm{C}_{\mathrm{sh}} / \mathrm{C}\right)_{\text {bare }}$
These proportions could then be converted into weight fractions of the model constituents using the carbon content of each constituent given in Table 3 .

Fig. 4(a) shows the protein and polysaccharide concentration (weight \%) determined on exponential- and stationary-phase cells of $A$. brasilense (Y.F. Dufrêne \& P. G. Rouxhet, unpublished). The data presented in Table 2 (mean values) were used for Fig. 4(b, c), which shows the surface composition determined on cell sediments, on polystyrene after cell sedimentation and mild rinsing, and on polystyrene after cell adhesion under various conditions and subsequent detachment; the balance is constituted of hydrocarbon-like compounds originating from both support and bacteria.

The protein to polysaccharide ratio of the cell sediment prepared at $4{ }^{\circ} \mathrm{C}$ (Fig. 4b, top) is similar to that observed on exponential-phase cells (Fig. 4a, top), the major constituent being polysaccharide. However, when the cell sediment is prepared at $30^{\circ} \mathrm{C}$, a relative increase of the surface protein content is observed; a similar increase is noted for stationary-phase cells as compared with exponential-phase cells. This observation, deduced from elemental composition, is consistent with the shape of $\mathrm{C}_{1 s}$ and $\mathrm{O}_{1 \mathrm{~s}}$ peaks as quantified by the data presented in Table 2: the cell sediment prepared at $30^{\circ} \mathrm{C}$ shows higher $\underline{\mathrm{C}}=\mathrm{O} / \underline{\mathrm{C}}-(\mathrm{O}, \mathrm{N})$ and $\underline{\mathrm{O}}=\mathrm{C} /(\mathrm{C}-\underline{\mathrm{O}}-\mathrm{C}, \mathrm{C}-\underline{\mathrm{O}} \mathrm{H})$ ratios compared to $4{ }^{\circ} \mathrm{C}$. It appears therefore that the surface of sedimented cells becomes richer in proteins when metabolism is favoured.

The supports analysed after sedimentation at $30^{\circ} \mathrm{C}$ and mild rinsing have a protein to polysaccharide ratio similar to that of cell sediment. The fact that lower protein and polysaccharide concentrations are observed, as compared to the cell sediment, is not surprising since the rinsing procedure removes all non-adhering cells, and thus several layers of cells, from the support.

The surface composition of the supports examined after detachment of adhering cells, harvested either in the exponential phase or in the stationary phase, after $24 \mathrm{~h}$ of contact at $30^{\circ} \mathrm{C}$, is very different from that of free cells and of cell sediments: apart from the presence of hydrocarbon-like compounds due to the original poly-

Table 3. Chemical composition of the model constituents considered for deduction of the molecular composition of surfaces

\begin{tabular}{|c|c|c|c|c|c|c|}
\hline Constituent & $\underline{\mathrm{C}}-(\mathrm{C}, \mathrm{H}) / \mathrm{C}$ & $\underline{\mathrm{C}}-(\mathbf{O}, \mathbf{N}) / \mathrm{C}$ & $\underline{\mathrm{C}}=\mathrm{O} / \mathrm{C}$ & $\mathrm{O} / \mathrm{C}$ & $\mathrm{N} / \mathrm{C}$ & $\begin{array}{l}\text { g constituent } \\
(\mathrm{mol} \mathrm{C})^{-1}\end{array}$ \\
\hline Protein* & $0 \cdot 428$ & $0 \cdot 293$ & $0 \cdot 279$ & $0 \cdot 325$ & $0 \cdot 279$ & $23 \cdot 0$ \\
\hline Polysaccharide & 0.000 & 0.833 & $0 \cdot 167$ & 0.833 & 0.000 & $27 \cdot 0$ \\
\hline Hydrocarbon & $1 \cdot 000$ & 0.000 & 0.000 & $0 \cdot 000$ & $0 \cdot 000$ & $14 \cdot 0$ \\
\hline Polystyrene & $1 \cdot 000$ & $0 \cdot 000$ & 0.000 & $0 \cdot 000$ & $0 \cdot 000$ & $13 \cdot 0$ \\
\hline
\end{tabular}

* Data computed from the amino acid analysis of the major outer-membrane protein of Pseudomonas fluorescens OE 28.3 (De Mot et al., 1992). 
(a) Free cells
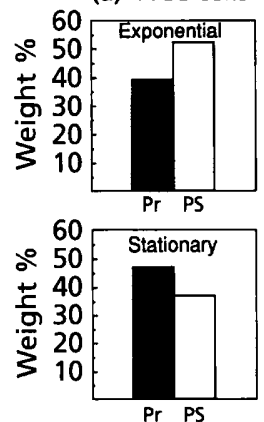

(c) Support after detachment of adhering cells
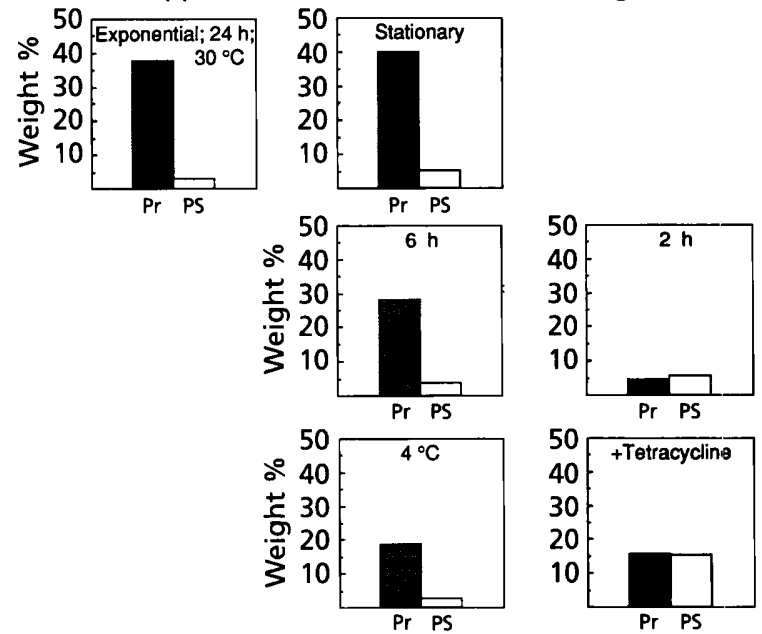

Fig. 4. Surface molecular composition deduced from XPS data, expressed in terms of protein (Pr) and polysaccharide (PS) concentration (weight \%): (a) A. brasilense cells harvested in the exponential phase and in the stationary phase (Y.F. Dufrêne \& P. G. Rouxhet, unpublished); (b) cell sediments prepared at $4{ }^{\circ} \mathrm{C}$ and at $30^{\circ} \mathrm{C}$, and polystyrene after cell sedimentation at $30^{\circ} \mathrm{C}$ and mild rinsing; (c) polystyrene after cell adhesion under different conditions and detachment: exponential-phase cells, $24 \mathrm{~h}$ contact time at $30^{\circ} \mathrm{C}$; stationaryphase cells, $24 \mathrm{~h}$ contact time at $30^{\circ} \mathrm{C}$; exponential-phase cells, $6 \mathrm{~h}$ and $2 \mathrm{~h}$ contact time at $30^{\circ} \mathrm{C}$; exponential-phase cells, $24 \mathrm{~h}$ contact time at $4{ }^{\circ} \mathrm{C}$, and at $30^{\circ} \mathrm{C}$ in the presence of tetracycline.

styrene and possibly to some biochemical compounds, it is composed essentially of proteins, the polysaccharide content being negligible (Fig. 4c, top). This observation, deduced from elemental composition, is in agreement with the shape of the $O_{1 \mathrm{~s}}$ peak (Fig. 2): for cells, the prevailing $\mathrm{O}_{1 \mathrm{~s}}$ component is due to $\mathrm{C}-\underline{\mathrm{O}} \mathrm{H}+\mathrm{C}-\underline{\mathrm{O}}-\mathrm{C}$, which reflects essentially the presence of polysaccharides, whereas for the supports analysed after cell detachment the major component is due to $\underline{O}=\mathrm{C}$, which reflects the presence of proteins. The two independent observations show that polysaccharides are characteristic of cells, whereas proteins are the major constituent at the support surface.

The contrast of protein/polysaccharide ratio between the support surface after cell detachment and the surface of cells, even those with the highest protein concentration (cell sediment, $24 \mathrm{~h}, 30^{\circ} \mathrm{C}$ ), indicates that the material remaining on the support is not made of cell surface fragments. It is also not compatible with shear occurring within the cell walls, which should lead to exposure of polysaccharides (peptidoglycan, lipopolysaccharides). Scanning electron microscope observation indeed confirmed that no cell debris remained on the support surface after sonication. The material remaining on the support surface is attributed to extracellular proteins that accumulated at the cell-support interface, the shear taking place within the layer of proteins or between this layer and the cells.

When the contact time is lowered to $6 \mathrm{~h}$ or $2 \mathrm{~h}$, when adhesion is carried out at $4{ }^{\circ} \mathrm{C}$ or when tetracycline is added, a smaller amount of biological compounds is detected at the support surface. Note that, due to the low concentrations, the relative proportion between proteins and polysaccharides is poorly significant.

\section{Biomolecules involved in the adhesion process}

The above discussion shows that changes of experimental conditions which affect the protein concentration at the cell surface (growth phase, temperature) or at the support surface (time, temperature, addition of tetracycline) influence the density of adhering cells in the same direction. This is illustrated in Fig. 5, which shows the relationship between the adhesion density and the N/C atomic concentration ratio determined by XPS on polystyrene supports, after detachment of adhering cells of $A$. brasilense. Clearly, two groups of data are distinguished: one characterized by very low adhesion densities and by low or intermediate $\mathrm{N} / \mathrm{C}$ ratios, corresponding to surface protein concentrations ranging from $5 \%$ to $30 \%$, the other characterized by high adhesion densities and high protein concentrations $(40 \%)$. This provides direct evidence that extracellular proteins play a role in the adhesion of $A$. brasilense to an inert surface.

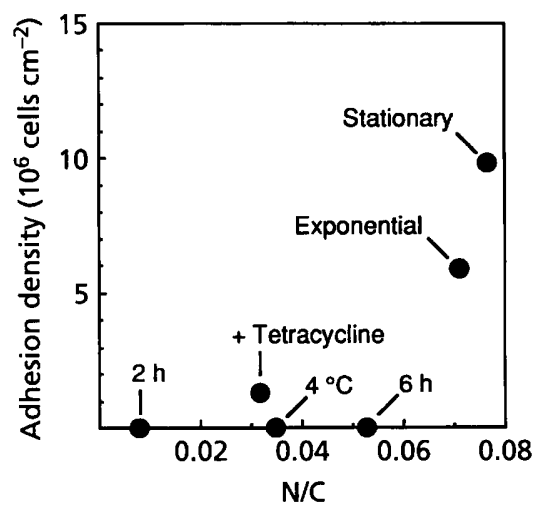

Fig. 5. Density of $A$. brasilense cells adhering on polystyrene under various conditions, as a function of the N/C atomic concentration ratio determined by XPS on the supports after detachment of adhering cells. 
These results may be related to biochemical and genetic studies, which suggested the involvement of surface proteins in the attachment of rhizobacteria, including Azospirillum, to plant roots or inert surfaces. Attachment of Klebsiella (Korhonen et al., 1983) and Enterobacter (Haahtela et al., 1985) strains to plant roots was clearly shown to be promoted by fimbriae. Pili have been found to be involved in the attachment of Bradyrbizobium japonicum to hydrophobic plastic surfaces and to soybean roots (Vesper \& Bauer, 1986). Vesper (1987) showed that the presence of pili on $P$. fluorescens, produced abundantly in low-nutrient medium, was quantitatively correlated with attachment to polystyrene, haemagglutination, and attachment to corn roots. Members of the Rhizobiaceae family, including Rhizobium, Bradyrbizobium and Agrobacterium spp., synthesize a rhicadhesin which promotes initial adhesion to plant surfaces (Smit et al., 1992). DeFlaun et al. (1990) showed that flagellin, a major outermembrane protein, is important for the adhesion of a $P$. fluorescens strain to sand. The major outer-membrane protein from the rhizosphere isolate $P$. fuorescens OE 28.3 adsorbed strongly and selectively to plant roots, indicating a potential role in root colonization (De Mot \& Vanderleyden, 1991).

Attachment of $A$. brasilense $\mathrm{Cd}$ to sand particles was found to be actively mediated by a network of fibrillar material, presumably proteinaceous (Bashan \& Levanony, 1988). Fibrillar material was also found to anchor the cells to root surfaces (Bashan et al., 1986). Michiels et al. (1991) showed, by the use of protease treatments, that adsorption of $A$. brasilense $\mathrm{Sp} 7$ to wheat roots was possibly mediated by proteinaceous compounds. Furthermore, a mutant deficient in expression of both polar and lateral flagella (Croes et al., 1991) failed to adsorb to wheat roots (Michiels et al., 1991). Croes et al. (1993) demonstrated that adsorption of $A$. brasilense to wheat roots is mediated by the polar flagellum. Madi et al. (1988) observed the formation of lateral flagella and fimbriae-like structures by A. brasilense $\mathrm{Cd}$ in static liquid culture and suggested that these filaments may play a role in cell-to-cell adhesion resulting in pellicle formation.

Surface polysaccharides are thought to be involved in attachment to plant roots (Michiels et al., 1991). At first glance, it may therefore be surprising that in the present study, the material remaining on the support after cell detachment was very poor in polysaccharides. Three interpretations may be taken into consideration. First, the attachment to plant roots was determined in a medium containing a carbon source which is known to favour polysaccharide production (Michiels et al., 1991). Second, extracellular polysaccharides may be involved not directly in the initial steps of the adhesion process, but rather in the subsequent stages of biofilm formation, as proposed for freshwater bacteria (Allison \& Sutherland, 1987). Third, bacterial surface polysaccharides may be involved only in the specific Azospirillum-plant root interaction, and not in the adhesion to inert surfaces. Specific interactions between bacterial saccharide receptors and plant root lectins have been suggested for Azospirillum associations (Umali-Garcia et al., 1980; Del Gallo et al., 1989; Zaady \& Okon, 1990).

Further work is needed to elucidate the mechanism(s) by which proteins influence adhesion: on the one hand, they may be released into the aqueous solution and adsorb on the support to create a conditioning film which in turn may influence adhesion; on the other hand, they may result from the in situ secretion of adhesive surface compounds by the adhering cells and thus lead to firm anchorage.

The possible action of the support surface in inducing the secretion of proteins by the cells may also be speculated. It is known that surface growth of $A$. brasilense induces the formation of lateral flagella (Hall \& Krieg, 1983; Moens et al., 1995). The same phenomenon is also known for Vibrio parabaemolyticus, where lateral flagella are believed to be involved in the adhesion to surfaces (Belas \& Colwell, 1982).

\section{Conclusions}

Adhesion of $A$. brasilense to glass and polystyrene depends on time and temperature, lower adhesion densities being observed when the contact time is only $2 \mathrm{~h}$ or $6 \mathrm{~h}$, as compared to $24 \mathrm{~h}$, or when the test is performed at $4{ }^{\circ} \mathrm{C}$, as compared to $30^{\circ} \mathrm{C}$. This points to the influence of cell physiology, which is demonstrated by the inhibition of adhesion as a result of the addition of tetracycline. Electron microscope observations show that $A$. brasilense cells produce extracellular material when they are left in contact with a support for $24 \mathrm{~h}$. The XPS analysis of cells and polystyrene supports has permitted an evaluation of the surface composition in terms of model molecular constituents. Proteins are the major constituent at the support surface after cell detachment. The comparison of the surface compositions of cell sediments prepared at $30{ }^{\circ} \mathrm{C}$ and at $4{ }^{\circ} \mathrm{C}$ indicates that the cell surface becomes richer in proteins when metabolism is favoured $\left(30^{\circ} \mathrm{C}\right)$; this may be related to the increase of cell surface protein concentration and cell adhesiveness observed during growth. Changes of experimental conditions (growth phase, temperature, time and addition of tetracycline) that affect the protein concentration at the cell surface or at the support surface have a corresponding influence on the adhesion density. This provides direct evidence for the involvement of extracellular proteins in the adhesion of $A$. brasilense to inert surfaces.

\section{ACKNOWLEDGEMENTS}

The authors thank N. Mozes, S. Moens and P. De Troch for fruitful discussion, and also the Center for Human Genetics of the Katholieke Universiteit Leuven for the use of their electron microscope facilities and B. Vanderschueren for her assistance. P.G.R. is a member of the Research Center for Advanced Materials. The support of the National Fund for Scientific Research (Y.F.D.), of the Department of Scientific Policy (PAISupramolecular Chemistry and Catalysis), and of the Department of Education and Scientific Research (Concerted Action Physical Chemistry of Interfaces and Biotechnology) is gratefully acknowledged. 


\section{REFERENCES}

Absolom, D. R., Lamberti, F. V., Policova, Z., Zingg, W., Van Oss, C. J. \& Neumann, A.W. (1983). Surface thermodynamics of bacterial adhesion. Appl Environ Microbiol 46, 90-97.

Allison, D. G. \& Sutherland, I. W. (1987). The role of exopolysaccharides in adhesion of freshwater bacteria. J Gen Microbiol 133, 1319-1327.

Bashan, Y. \& Holguin, G. (1993). Anchoring of Azospirillum brasilense to hydrophobic polystyrene and wheat roots. I Gen Microbiol 139, 379-385.

Bashan, Y. \& Levanony, H. (1988). Active attachment of Azospirillum brasilense $\mathrm{Cd}$ to quartz sand and to a light-textured soil by protein bridging. J Gen Microbiol 134, 2269-2279.

Bashan, Y., Levanony, H. \& Klein, E. (1986). Evidence for a weak active external adsorption of Azospirillum brasilense $\mathrm{Cd}$ to wheat roots. J Gen Microbiol 132, 3069-3073.

Bashan, Y., Mitiku, G., Whitmoyer, R. E. \& Levanony, H. (1991). Evidence that fibrillar anchoring is essential for Azospirillum brasilense $\mathrm{Cd}$ attachment to sand. Plant Soil 132, 73-83.

Belas, M. R. \& Colwell, R. R. (1982). Adsorption kinetics of laterally and polarly flagellated Vibrio.J Bacteriol 151, 1568-1580.

Busscher, H. J., Weerkamp, A. H., van der Mei, H. C., van Pelt, A. W. J., de Jong, H. P. \& Arends, J. (1984). Measurement of the surface free energy of bacterial cell surfaces and its relevance for adhesion. Appl Environ Microbiol 48, 980-983.

Characklis, W. G. \& Marshall, K. C. (1990). Biofilms. New York: Wiley-Interscience.

Croes, C., Van Bastelaere, E., DeClercq, E., Eyers, M., Vanderleyden, J. \& Michiels, K. (1991). Identification and mapping of loci involved in motility, adsorption to wheat roots, colony morphology, and growth in minimal medium on the Azospirillum brasilense Sp7 90-MDa plasmid. Plasmid 26, 83-93.

Croes, C. L., Moens, S., van Bastelaere, E., Vanderleyden, J. \& Michiels, K. W. (1993). The polar flagellum mediates Azospirillum brasilense adsorption to wheat roots. J Gen Microbiol 139, 2261-2269.

DeFlaun, M. F., Tanzer, A. S., McAteer, A. L., Marshall, B. \& Levy, S. B. (1990). Development of an adhesion assay and characterization of an adhesion-deficient mutant of Pseudomonas fuorescens. Appl Environ Microbiol 56, 112-119.

Del Gallo, M., Negi, M. \& Neyra, C. A. (1989). Calcofluor-- and lectin-binding exocellular polysaccharides of Azospirillum brasilense and Azospirillum lipoferum. $J$ Bacteriol 171, 3504-3510.

De Mot, R. \& Vanderleyden, J. (1991). Purification of a rootadhesive outer membrane protein of root-colonizing Pseudomonas fuorescens. FEMS Microbiol Lett 81, 323-328.

De Mot, R., Proost, P., Van Damme, J. \& Vanderleyden, J. (1992). Homology of the root adhesin of Pseudomonas fiuorescens OE 28.3 with porin F of $P$. aeruginosa and $P$. syringae. Mol $\&$ Gen Genet 231, 489-493.

Eyers, M., Vanderleyden J. \& Van Gool, A. (1988). Attachment of Azospirillum to isolated plant cells. FEMS Microbiol Lett 49, 435-439.

Fletcher, M. (1980). The question of passive versus active attachment mechanisms in non-specific bacterial adhesion. In Microbial Adbesion to Surfaces, pp. 197-210. Edited by R. C. W. Berkeley, J. M. Lynch, J. Melling, P. R. Rutter \& B. Vincent. Chichester: Ellis Horwood.

Fletcher, M. \& Floodgate, G. D. (1973). An electron-microscopic demonstration of an acidic polysaccharide involved in the adhesion of a marine bacterium to solid surfaces. J Gen Microbiol 74, 325--334.
Gafny, R., Okon, Y. \& Kapulnik, Y. (1986). Adsorption of Azospirillum brasilense to corn roots. Soil Biol Biochem 18, 69-75.

Gerin, P. A., Dengis, P. B. \& Rouxhet, P. G. (1995). Performance of XPS analysis of model biochemical compounds. J Chim Phys $\mathbf{9 2 ,}$ 1043-1065.

Haahtela, K., Tarkka, E. \& Korhonen, T. K. (1985). Type 1 fimbriamediated adhesion of enteric bacteria to grass roots. Appl Environ Microbiol 49, 1182-1185.

Hall, P. G. \& Krieg, N. R. (1983). Swarming of Azospirillum brasilense on solid media. Can J Microbiol 29, 1592-1594.

Korhonen, T. K., Tarkka, E., Ranta, H. \& Haahtela, K. (1983). Type 3 fimbriae of Klebsiella sp.: molecular characterization and role in bacterial adhesion to plant roots. J Bacteriol 155, 860-865.

van Loosdrecht, M. C. M., Lyklema, J., Norde, W., Schraa, G. \& Zehnder, A. J. B. (1987). The role of bacterial cell wall hydrophobicity in adhesion. Appl Environ Microbiol 53, 1893-1897.

van Loosdrecht, M. C. M., Lyklema, J., Norde, W. \& Zehnder, A. J. B. (1989). Bacterial adhesion: a physicochemical approach. Microb Ecol 17, 1-15.

Madi, L. \& Henis, Y. (1989). Aggregation in Azospirillum brasilense $\mathrm{Cd}$ : conditions and factors involved in cell-to-cell adhesion. Plant Soil 115, 89-98.

Madi, L., Kessel, M., Sadovnik, E. \& Henis, Y. (1988). Electron microscopic studies of aggregation and pellicle formation in Azospirillum spp. Plant Soil 109, 115-121.

Marshall, K. C. (1985). Mechanisms of bacterial adhesion at solid-water interfaces. In Bacterial Adhesion, pp. 133-161. Edited by D. C. Savage \& M. Fletcher. New York \& London: Plenum Press.

Marshall, K. C. (1991). The importance of studying microbial cell surfaces. In Microbial Cell Surface Analysis: Structural and Pbysicochemical Methods, pp. 3-19. Edited by N. Mozes, P. S. Handley, H. J. Busscher \& P. G. Rouxhet. New York: VCH.

Marshall, K. C. \& Cruickshank, R. H. (1973). Cell surface hydrophobicity and the orientation of certain bacteria at interfaces. Arch Mikrobiol 91, 29-40.

Marshall, K. C., Stout, R. \& Mitchell, R. (1971). Mechanism of the initial events in the sorption of marine bacteria to surfaces. $J$ Gen Microbiol 68, 337-348.

Melo, L. F., Bott, T. R., Fletcher, M. \& Capdeville, B. (1992). Biofilms - Science and Technology. Dordrecht: Kluwer.

Michiels, K., Vanderleyden, J. \& Van Gool, A. (1989). Azospirillum-plant root associations: a review. Biol Fertil Soils 8, 356-368.

Michiels, K. W., Croes, C. L. \& Vanderleyden, J. (1991). Two different modes of attachment of Azospirillum brasilense Sp7 to wheat roots. J Gen Microbiol 137, 2241-2246.

Moens, S., Michiels, K., Keijers, V., Van Leuven, F. \& Vanderleyden, J. (1995). Cloning, sequencing, and phenotypic analysis of laf1, encoding the flagellin of the lateral flagella of Azospirillum brasilense Sp7. J Bacteriol 177, 5419-5426.

Mozes, N., Marchal, F., Hermesse, M.-P., van Haecht, J.-L., Reuliaux, L., Leonard, A. J. \& Rouxhet, P. G. (1987). Immobilization of microorganisms by adhesion: interplay of electrostatic and nonelectrostatic interactions. Biotechnol Bioeng 30, 439-450.

Neu, T. R. \& Marshall K. C. (1991). Microbial 'footprints' - a new approach to adhesive polymers. Biofouling 3, 101-112.

Okon, Y. (1994). Aqospirillum/Plant Associations. Boca Raton, FL: CRC Press.

Peros, W. J. \& Gibbons, R. J. (1982). Influence of sublethal 
antibiotic concentrations on bacterial adherence to saliva-treated hydroxyapatite. Infect Immun 35, 326-334.

Peros, W. J., Etherden, I., Gibbons, R. J. \& Skobe, Z. (1985). Alteration of fimbriation and cell hydrophobicity by sublethal concentrations of tetracycline. J Periodont Res 20, 24-30.

Ratner, B. D. \& McElroy, B. J. (1986). Electron spectroscopy for chemical analysis: applications in the biomedical sciences. In Spectroscopy in the Biomedical Sciences, pp. 107-140. Edited by R. M. Gendreau. Boca Raton, FL: CRC Press.

Rijnaarts, H. H. M., Norde, W., Bouwer, E. J., Lyklema, J. \& Zehnder, A. J. B. (1995). Reversibility and mechanism of bacterial adhesion. Colloids Surfaces B: Biointerfaces 4, 5-22.

Rouxhet, P. G. \& Genet, M. J. (1991). Chemical composition of the microbial cell surface by X-ray photoelectron spectroscopy. In Microbial Cell Surface Analysis: Structural and Physico-chemical Methods, pp. 173-220. Edited by N. Mozes, P. S. Handley, H. J. Busscher \& P. G. Rouxhet. New York: VCH.

Rouxhet, P. G. \& Mozes, N. (1990). Physical chemistry of the interface between attached micro-organisms and their support. Wat Sci Technol 22, 1-16.

Rouxhet, P. G., Mozes, N., Dengis, P. B., Dufrêne, Y. F., Gerin, P. A. \& Genet, M. J. (1994). Application of X-ray photoelectron spectroscopy to microorganisms. Colloids Surfaces B: Biointerfaces 2 , 347-369.
Sambrook, J., Fritsch, E. F. \& Maniatis, T. (1989). Molecular Cloning: a Laboratory Manual, 2nd edn. Cold Spring Harbor, NY: Cold Spring Harbor Laboratory.

Scofield, J. H. (1976). Hartree-Slater subshell photoionization cross-sections at 1254 and $1487 \mathrm{eV}$. J Electron Spectrosc Relat Phenom 8, 129-137.

Smit, G., Swart, S., Lugtenberg, B. J. J. \& Kijne, J. W. (1992). Molecular mechanisms of attachment of Rhizobium bacteria to plant roots. Mol Microbiol 6, 2897-2903.

Umali-Garcia, M., Hubbell, D. H., Gaskins, M. H. \& Dazzo, F. B. (1980). Association of Arospirillum with grass roots. Appl Environ Microbiol 39, 219-226.

Vesper, S. J. (1987). Production of pili (fimbriae) by Pseudomonas fluorescens and correlation with attachment to corn roots. Appl Environ Microbiol 53, 1397-1405.

Vesper, S. J. \& Bauer, W. D. (1986). Role of pili (fimbriae) in attachment of Bradyrbizobium japonicum to soybean roots. Appl Environ Microbiol 52, 134-141.

Zaady, E. \& Okon, Y. (1990). Cultural conditions affecting Azospirillum brasilense cell aggregation and adsorption to maize roots. Soil Biol Biochem 22, 1103-1107.

Received 13 July 1995; revised 3 November 1995; accepted 28 November 1995. 